\title{
Excitatory Actions of Endogenously Released GABA Contribute to Initiation of Ictal Epileptiform Activity in the Developing Hippocampus
}

\author{
Volodymyr I. Dzhala and Kevin J. Staley \\ Department of Neurology and Pediatrics, University of Colorado Health Sciences Center, Denver, Colorado 80262
}

\begin{abstract}
In the developing rat hippocampus, ictal epileptiform activity can be elicited easily in vitro during the first three postnatal weeks. Changes in neuronal ion transport during this time cause the effects of $\mathrm{GABA}_{\mathrm{A}}$ receptor $\left(\mathrm{GABA}_{\mathrm{A}}-\mathrm{R}\right)$ activation to shift gradually from strongly depolarizing to hyperpolarizing. It is not known whether the depolarizing effects of GABA and the propensity for ictal activity are causally linked. A key question is whether the GABA-mediated depolarization is excitatory, which we defined operationally as being sufficient to trigger action potentials. We assessed the effect of endogenous GABA on ictal activity and neuronal firing rate in hippocampal slices from postnatal day $1(\mathrm{P} 1)$ to $\mathrm{P} 30$. In extracellular recordings, there was a strong correlation between the postnatal age at which $\mathrm{GABA}_{\mathrm{A}}-\mathrm{R}$ antagonists decreased action potential frequency (P23) and the age at which ictal activity could be induced by elevated potassium (P23). In addition, there was a strong correlation between the fraction of slices in which ictal activity was induced by elevated potassium concentrations and the fractional decrease in action potential firing when $\mathrm{GABA}_{\mathrm{A}}-\mathrm{Rs}$ were blocked in the presence of ionotropic glutamate receptor antagonists. Finally, ictal activity induced by elevated potassium was blocked by the $\mathrm{GABA}_{\mathrm{A}}-\mathrm{R}$ antagonists bicuculline and SR-95531 (gabazine) and increased in frequency and duration by $\mathrm{GABA}_{\mathrm{A}}-\mathrm{R}$ agonists isoguvacine and muscimol. Thus, the propensity of the developing hippocampus for ictal activity is highly correlated with the effect of GABA on action potential probability and reversed by $\mathrm{GABA}_{\mathrm{A}}$ antagonists, indicating that GABA-mediated excitation is causally linked to ictal activity in this developmental window.
\end{abstract}

Key words: GABA; action potential; epileptiform activity; hippocampus; CA3; development

\section{Introduction}

Despite dramatically lower synaptic connectivity (Bayer, 1980; Gomez-Di Cesare et al., 1997), the immature brain is much more susceptible to seizures than the adult brain (DeLorenzo et al., 1992; Holmes, 1997). Modeling studies clearly indicate that synchronous activity is not easily maintained when synaptic connectivity is low (Traub and Miles, 1991). Thus, there must be a compelling proconvulsant factor or factors that increase seizure propensity in the immature brain.

One likely proconvulsant factor is the paradoxical action of the neurotransmitter GABA. $\mathrm{GABA}_{\mathrm{A}}$ receptor $\left(\mathrm{GABA}_{\mathrm{A}}-\mathrm{R}\right)$ activation is inhibitory in the adult brain, both by virtue of the membrane hyperpolarization induced by chloride $\left(\mathrm{Cl}^{-}\right)$influx through the $\mathrm{GABA}_{\mathrm{A}}$ ionophore and by virtue of shunting of dendritic excitatory inputs (Koch et al., 1983; Staley and Mody, 1992). In the immature brain, however, the transmembrane chloride gradient is reversed, so that $\mathrm{GABA}_{\mathrm{A}}-\mathrm{R}$ activation depolarizes the neuronal membrane (Cherubini et al., 1991; Owens et al., 1996; Ben Ari et al., 1997). GABAergic circuits develop early during development (Tyzio et al., 1999), and thus it seems reasonable that the propensity for seizure activity in the immature brain could be a consequence of additional feedback excitation

\footnotetext{
Received 0ct. 1, 2002; revised Dec. 6, 2002; accepted Dec. 19, 2002.

This work was supported by a grant from the National Institutes of Health, National Institute of Neurological Disorders and Stroke.

Correspondence should be addressed to Kevin J. Staley, Department of Neurology and Pediatrics, University of Colorado Health Sciences Center, 4200 East Ninth Avenue, B182, Denver, C0 80262.E-mail: kevin.staley@uchsc.edu. Copyright $\odot 2003$ Society for Neuroscience $\quad 0270-6474 / 03 / 231840-07 \$ 15.00 / 0$
}

mediated through the GABAergic circuits that subserve feedback inhibition in the adult nervous system (Alger and Nicoll, 1982; Freund and Buzsaki, 1996). However, experimental evidence has not clearly supported this idea. In the developing hippocampus, although some physiological forms of synchronous activity are blocked by $\mathrm{GABA}_{\mathrm{A}}-\mathrm{R}$ antagonists (Ben Ari et al., 1989; Khalilov et al., 1999), epileptiform activity is not (Wells et al., 2000). Furthermore, epileptiform activity can be suppressed by $\mathrm{GABA}_{\mathrm{A}}-\mathrm{R}$ agonists (Wells et al., 2000).

One difficulty associated with determining the role of GABA in the developing hippocampus is the tenuous nature of the ion gradients that underlie the effects of $\mathrm{GABA}_{\mathrm{A}}-\mathrm{R}$ activation in this age range (Staley and Smith, 2001). Even in adult neurons, in which GABA is strongly hyperpolarizing, overactivation of $\mathrm{GABA}_{\mathrm{A}}-\mathrm{R}$ can overwhelm $\mathrm{K}-\mathrm{Cl}$ cotransport such that the $\mathrm{Cl}^{-}$ reversal potential $\left(\mathrm{ECl}^{-}\right)$is driven to the resting membrane potential (RMP) (Thompson and Gahwiler, 1989a). This effect becomes more pronounced as $\mathrm{K}-\mathrm{Cl}$ cotransport is compromised by increased extracellular $\mathrm{K}^{+}\left(\left[\mathrm{K}^{+}\right]_{\mathrm{o}}\right)$ concentrations (Staley and Proctor, 1999). If $\mathrm{Cl}^{-}$gradients in developing neurons are similarly labile, application of GABA agonists might cause $\mathrm{ECl}^{-}$to move negatively toward RMP. In this case, additional $\mathrm{GABA}_{\mathrm{A}}-\mathrm{R}$ activation would not depolarize the membrane further, so that shunting inhibition would be the dominant effect of $\mathrm{GABA}_{\mathrm{A}}-\mathrm{R}$ activation. This may explain the anticonvulsant effects of exogenous agonists in the neonatal period.

To resolve this issue, we need to determine the effect of endogenously released GABA. One way to determine whether GABA is excitatory is by determining whether or not $\mathrm{GABA}_{\mathrm{A}}-\mathrm{R}$ activation 
triggers action potentials. Measuring the effects of synaptic $\mathrm{GABA}_{\mathrm{A}}-\mathrm{R}$ activation on the basis of intracellular recordings can be complicated by dialysis of the cytoplasmic $\mathrm{Cl}^{-}$by the electrode solution (Staley and Proctor, 1999) and by electrode-induced shifts in RMP and action potential threshold (Staley and Mody, 1991). Although dialysis issues can be overcome by perforated patch recordings (Owens et al., 1996), the antibiotic used to perforate the membrane can diffuse through the membrane away from the patch, decreasing the membrane resistivity and thereby increasing the amount of current necessary to reach action potential threshold. Thus, perforated patch recordings are useful for determination of the reversal potential of the $G_{A B A}-R$ mediated responses (EGABA) but not the relationship between EGABA and action potential generation. In this study, we circumvented these difficulties by measuring extracellular unit activity (Cohen and Miles, 2000; Dzhala et al., 2001) as an assay of the net effect of $\mathrm{GABA}_{\mathrm{A}}-\mathrm{R}$ or activation by endogenously released GABA. These actions were correlated with the effects of $\mathrm{GABA}_{\mathrm{A}}-\mathrm{R}$ activation on ictal epileptiform activity at different developmental ages.

\section{Materials and Methods}

Experimental systems. Hippocampal slices were prepared from male Wistar rats at age postnatal day 1 (P1) to P30. The first $24 \mathrm{hr}$ after birth were designated $\mathrm{P} 0$. All animal use protocols conformed to the University of Colorado Health Sciences Center animal care and use committee and the National Institutes of Health guidelines on the use of laboratory animals. Animals were anesthetized with chloral hydrate $(350 \mathrm{mg} / \mathrm{kg}$, i.p.) and decapitated. The brain was removed rapidly and placed in an oxygenated $\left(95 \% \mathrm{O}_{2}-5 \% \mathrm{CO}_{2}\right)$ ice-cold artificial CSF (aCSF) of the following composition (in mM): $126 \mathrm{NaCl}, 3.5 \mathrm{KCl}, 2.0 \mathrm{CaCl}_{2}, 1.3 \mathrm{MgCl}_{2}, 25$ $\mathrm{NaHCO}_{3}, 1.2 \mathrm{NaH}_{2} \mathrm{PO}_{4}$, and 11 glucose, at a $\mathrm{pH}$ of 7.4. Hippocampal transverse slices (thickness of $0.6-0.7 \mathrm{~mm}$ ) were cut with a VT $1000 \mathrm{~S}$ vibroslicer (Leica, Nussloch, Germany) and kept in oxygenated (95\% $\left.\mathrm{O}_{2}-5 \% \mathrm{CO}_{2}\right) \mathrm{aCSF}$ at room temperature $\left(20-22^{\circ} \mathrm{C}\right)$ at least $1 \mathrm{hr}$ before use. Unusually thick hippocampal slices were used to preserve the advantages of the intact hippocampal preparation in vitro (Khalilov et al., 1997). There was no correlation between extracellularly recorded action potential frequency and electrode depth, indicating that, if the oxygen tension was lower in the center of our 700- $\mu$ m-thick slices, it did not affect neuronal or network excitability.

Electrophysiological recordings and data analysis. For electrophysiological recordings, individual slices were transferred to a conventional submersion-type chamber and superfused continuously with oxygenated aCSF at $32^{\circ} \mathrm{C}$ at a rate of $2-3 \mathrm{ml} / \mathrm{min}$. Whole-cell and extracellular field potential recordings were performed in the CA3 pyramidal cell layer. Whole-cell recordings were made using an Axopatch 200 (Axon Instruments, Foster City, CA) amplifier. Patch electrodes were made from borosilicate glass capillaries (G150F-4; Warner Instruments, Hamden, CT) and had a resistance of $5 \mathrm{M} \Omega$ when filled with solution containing the following (in $\mathrm{mm}$ ): 135 potassium gluconate, $0.1 \mathrm{CaCl}_{2}, 2.0$ $\mathrm{MgCl}_{2}, 2.0 \mathrm{Na}_{2} \mathrm{ATP}, 1.0 \mathrm{EGTA}$, and 10 HEPES, at a pH of 7.25. The liquid junction potential was measured $(+11 \mathrm{mV})$, and voltages reported are corrected values.

Extracellular field potentials were recorded using tungsten microelectrodes and a multichannel amplifier (bandpass, $0.1 \mathrm{~Hz}$ to $4 \mathrm{kHz}$; 1000×) with enhanced electromagnetic interference noise suppression developed for neurobiology research applications (TRINITI; Troitsk, Moscow, Russia). Use of microelectrodes made from coated tungsten wire 50 $\mu \mathrm{m}$ in diameter (California Fine Wire Company, Grover Beach, CA) enables simultaneous recordings of multiple-unit activity (MUA) (400 $\mathrm{Hz}$ high-pass filter) and population field activity (EEG band, 1-100 Hz) from tens to hundreds of neurons near each electrode (Cohen and Miles, 2000). Root-mean-square noise level with an electrode placed in the perfusion solution was typically $4-5 \mu \mathrm{V}$, whereas the amplitude of action potentials recorded from the stratum pyramidale ranged from this noise level up to $200 \mu \mathrm{V}$. The signals were digitized using an analog-to-digital converter (DigiData 1322A; Axon Instruments). Axoscope and Clampfit (Axon Instruments), Mini Analysis Program (Synaptosoft, Decatur, GA), and Origin (Microcal Software, Northampton, MA) programs were used for the acquisition and data analysis. The MUA was determined from high-pass filtered $(400 \mathrm{~Hz})$ raw data with a spike detection algorithm (Mini Analysis Program) and verified visually. Spikes with amplitude greater than three times the root-mean-square noise level were accepted.

Group measures are expressed as mean \pm SEM; error bars also indicate SEM. The statistical significance of differences was assessed with the Student's $t$ test. The level of significance was set at $p<0.05$.

Drugs. Drugs were purchased from Sigma (St. Louis, MO) and Tocris Cookson (Ellisville, MO), prepared as stock solutions, divided into aliquots, and stored in tightly sealed vials at recommended temperatures. During the experiments, thawed aliquots were kept on ice and protected from light until use.

\section{Results}

Extracellular unit activity and population field activity were measured in the CA3 pyramidal cell layer to circumvent potential problems associated with cell dialysis from patch electrodes. Resting membrane potential was measured using whole-cell recordings. In control conditions, the resting membrane potential of CA3 pyramidal cells gradually shifted from $-73 \pm 1.5 \mathrm{mV}$ at $\mathrm{P} 8-\mathrm{P} 12(n=10)$ to $-80.5 \pm 2.1 \mathrm{mV}$ at P26-P30 $(n=8)$. Despite the use of thick $(0.6-0.7 \mathrm{~mm})$ hippocampal slices, no anoxiaassociated network oscillations or rapid neuronal depolarization have been observed (Dzhala et al., 2001)

\section{Contributions of synaptic activities to firing rates of hippocampal neurons}

In control conditions, spontaneous action potentials were invariably detected in extracellular field potential recordings from the CA3 pyramidal cell layer in neonatal rat hippocampal slices (Fig. $1 A)$. We used pharmacological tools to estimate the degree to which synaptic excitation and inhibition altered this activity. Bath application of the AMPA-receptor antagonist 2,3dihydroxy-6-nitro-7-sulfonyl-benzo[f] quinoxaline (NBQX) (10 $\mu \mathrm{M})$ and the NMDA-receptor antagonist D-2-amino-7phosphonovalerate (D-APV) $(50 \mu \mathrm{M})$ reduced neuronal firing rate from $94 \pm 2.4 \%$ at $\mathrm{P} 1(n=6$ slices; $p=0.0045)$ to $44 \pm 12 \%$ at P30 ( $n=5$ slices; $p=0.0037)$. Subsequent application of the $\mathrm{GABA}_{\mathrm{A}}-\mathrm{R}$ antagonist bicuculline $(10 \mu \mathrm{M})$ in the presence of NBQX and D-APV diminished firing rate further up to P12, indicating that endogenous activation of $\mathrm{GABA}_{\mathrm{A}}-\mathrm{R}$ increases the frequency of neuronal firing. Our experiments confirm previously reported data from cell-attached recordings in the P2-P5 hippocampal slices (Khalilov et al., 1999). After P12, bicuculline increased the neuronal firing rate when AMPA and NMDA receptors were blocked, indicating that endogenously released GABA had a net inhibitory effect (Fig. $1 B, C$ ).

Ictal epileptiform patterns can be elicited in the neonatal brain slice by increasing $\left[\mathrm{K}^{+}\right]_{\mathrm{o}}$ to $8.5 \mathrm{~mm}$ (Fig. 2A) (see Figs. 3-7) (Rutecki et al., 1985). This $\left[\mathrm{K}^{+}\right]_{\mathrm{o}}$ diminishes neuronal $\mathrm{Cl}^{-}$extrusion by decreasing the driving force for $\mathrm{K}-\mathrm{Cl}$ cotransport, thereby making the GABA reversal potential more positive (Thompson and Gahwiler, 1989b). This would make GABA more strongly depolarizing in neurons expressing the $\mathrm{K}-\mathrm{Cl}$ cotransporters (Rivera et al., 1999). Elevated $\left[\mathrm{K}^{+}\right]_{\mathrm{o}}$ also depolarizes the neuronal membrane, decreasing the amount of depolarization needed to trigger action potentials. Thus, exogenously released GABA would be expected to elicit more action potentials in the presence of elevated $\left[\mathrm{K}^{+}\right]_{\mathrm{o}}$ as the depolarization induced by GABA increases and the distance between RMP and action 


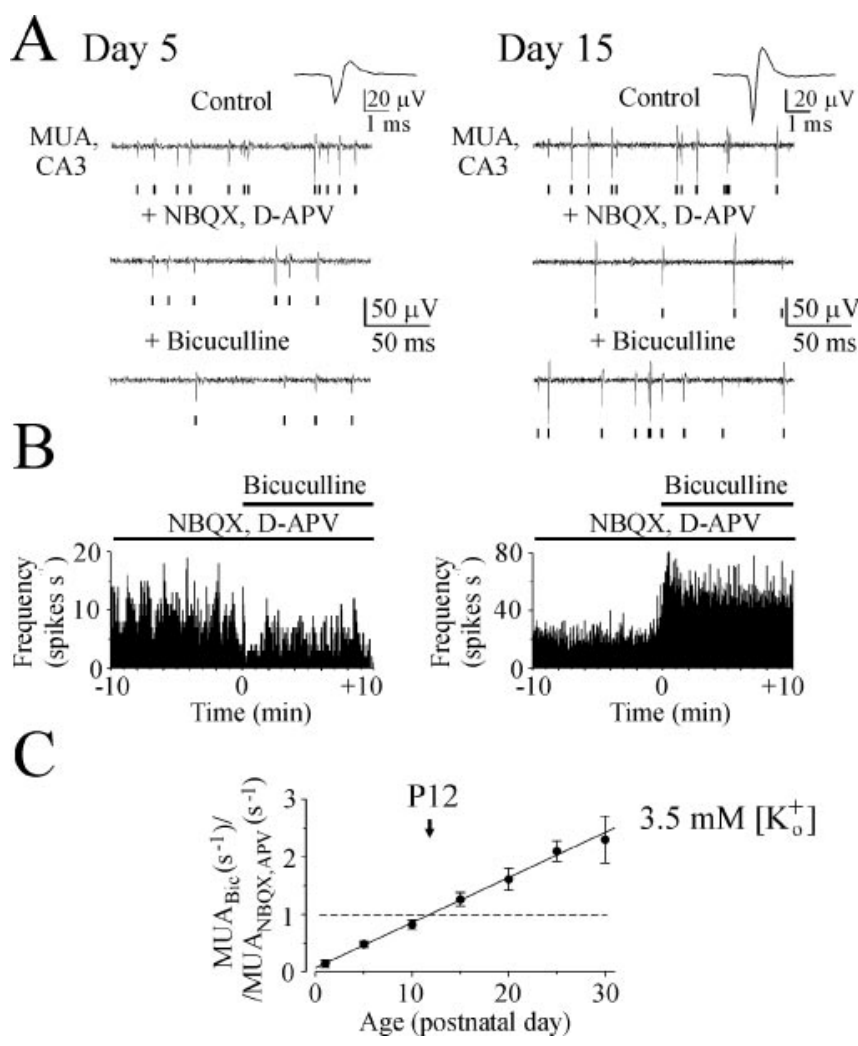

Figure 1. Effects on neuronal firing rate of suppression synaptic excitation and inhibition in control conditions. A, Glutamate receptor antagonists NBQX (10 $\mu \mathrm{m})$ and D-APV $(50 \mu \mathrm{M})$ reduced neuronal firing rate in P5 (left traces) and P15 (right traces) rat hippocampal slices. Subsequent application of the $G_{A B A_{A}}-R$ antagonist bicuculline $(10 \mu \mathrm{M})$, in the presence of NBQX and $\mathrm{D}-\mathrm{APV}$, diminished neuronal firing at $\mathrm{P} 5$ further and increased the firing rate at $\mathrm{P} 15$. Examples of extracellular recordings from the CA3 pyramidal cell layer filtered for the MUA $(400 \mathrm{~Hz}$ high-pass filter). Detected spikes are marked by vertical bars. Insets, Averaged spikes from extracellular recordings. $B$, The frequency of MUA recorded from the CA3 pyramidal cell layer after the application of NBQX and D-APV and then after the application of bicuculline. C, Age dependence of the effect on MUA of suppression synaptic excitation and inhibition at $3.5 \mathrm{~mm}$ $\left[\mathrm{K}^{+}\right]_{0}$.

potential threshold decreases. In $8.5 \mathrm{~mm}\left[\mathrm{~K}^{+}\right]_{\mathrm{o}}$, the $\mathrm{GABA}_{\mathrm{A}}-\mathrm{R}$ antagonist bicuculline, when AMPA and NMDA receptors were blocked, diminished firing rate in the CA3 subfield by $79 \pm 7 \%$ at $\mathrm{P} 1(n=12$ records from five slices $)$ and $9 \pm 10 \%$ at $\mathrm{P} 22(n=9$ records from three slices), indicating that endogenous GABA was excitatory. At P25, firing rate increased to $109 \pm 8 \%$ of control ( $n=9$ records from three slices) and at P30 to $149 \pm 21 \%$ of control ( $n=9$ records from three slices) (Fig. $2 C)$. These data from immature animals are in contrast to the effects of GABA antagonists in hippocampal slices from mature rodents (Cohen and Miles, 2000), in which the rate of spike discharge increased to $177 \pm 71 \%$ of its control value, indicating that endogenous GABA is strongly inhibitory.

When the $\left[\mathrm{K}^{+}\right]_{\mathrm{o}}$ concentration was varied, endogenously released GABA triggered progressively more action potentials at higher concentrations of $\left[\mathrm{K}^{+}\right]_{\mathrm{o}}(n=18$ slices) (Fig. $3 A)$. To determine whether this effect of $\left[\mathrm{K}^{+}\right]_{\mathrm{o}}$ on neuronal firing rate was correlated with ictal epileptiform activity triggered by $\left[\mathrm{K}^{+}\right]_{\mathrm{o}}$, we perfused $\mathrm{P} 10-\mathrm{P} 11$ rat hippocampal slices with solutions containing elevated concentrations of extracellular potassium (Jensen and Yaari, 1988, 1997; Traynelis and Dingledine, 1988). Of the hippocampal slices from P10-P11 rats, 71.4\% displayed recurrent ictal epileptiform activities at $8.5 \mathrm{~mm}\left[\mathrm{~K}^{+}\right]_{0}$, and a threshold for the proconvulsant effect of $\left[\mathrm{K}^{+}\right]_{\mathrm{o}}$ was seen at 7.5

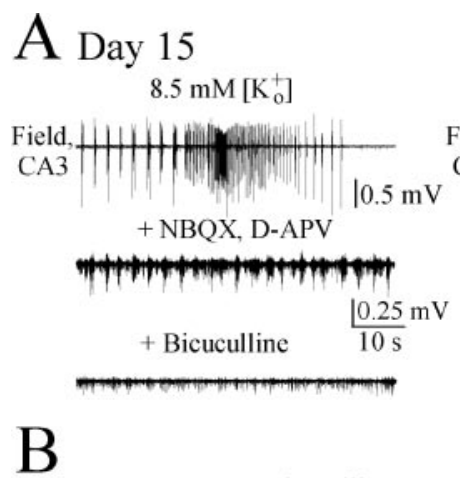

Day 30
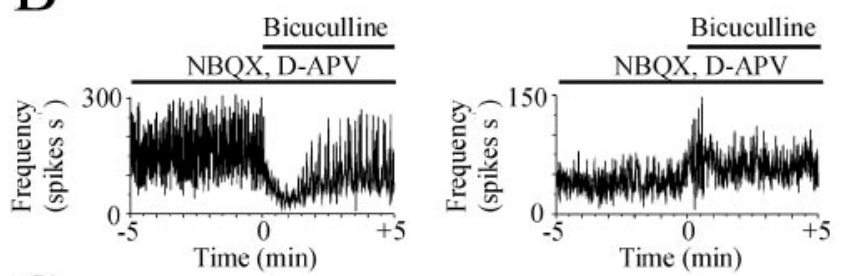

$\mathcal{C}$

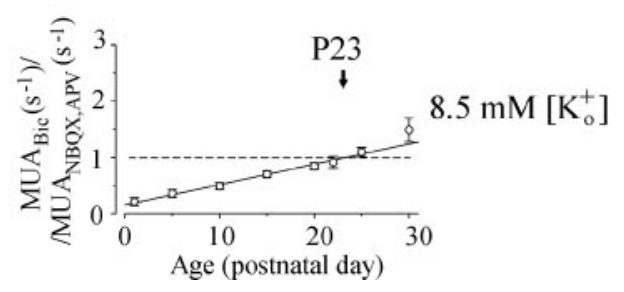

Figure 2. Effects on neuronal firing rate and epileptiform activities of suppression synaptic excitation and inhibition at $8.5 \mathrm{~mm}\left[\mathrm{~K}^{+}\right]_{0}$. A, Glutamate receptor antagonists NBQX $(10 \mu \mathrm{M})$ and D-APV $(50 \mu \mathrm{M})$ abolish $8.5 \mathrm{~mm}\left[\mathrm{~K}^{+}\right]_{0}$-induced interictal and ictal epileptiform activity in P15 (left traces) and interictal epileptiform discharges in P30 (right traces) rat hippocampal slices. GABA $A_{A}-R$ antagonist bicuculline $(10 \mu \mathrm{m})$ diminishes neuronal firing at P15 and increases the firing rate at $P 30$. Extracellular recordings from $C A 3$ pyramidal cell layer. $B$, The frequency of MUA (in sec ${ }^{-1}$ ) recorded from the CA3 pyramidal cell layer after the application of NBQX and D-APV and then after the application of bicuculline. C, Age dependence of the effect on MUA of suppression synaptic excitation and inhibition at $8.5 \mathrm{~mm}\left[\mathrm{~K}^{+}\right]_{0}$.

$\mathrm{mm}\left[\mathrm{K}^{+}\right]_{\mathrm{o}}(16.7 \%$ of the hippocampal slices displayed ictal activity), which was similar to the $\left[\mathrm{K}^{+}\right]_{\mathrm{o}}$ effect on action potential generation (Fig. $3 A, B$ ).

\section{Ictal epileptiform activity induced by high $\left[\mathrm{K}^{+}\right]_{\mathrm{o}}$ in the rat hippocampal slices}

In the hippocampal slices from P5 rats, bath application of 8.5 $\mathrm{mm} \mathrm{K}^{+}$induced a progressive increase in neuronal firing that developed to interictal epileptiform discharges (Pedley, 1980). Interictal epileptiform discharges (IEDs) were generated regularly with an averaged interval $1.08 \pm 0.1 \mathrm{sec}(n=6$ slices from P5 rats) and consisted of a large-amplitude primary population spike and a subsequent slow spike wave. IEDs were initiated in the CA3a-CA3b pyramidal cell layer and propagated bidirectionally to the distal CA1 and dentate gyrus. Before transition to ictal epileptiform activity, IEDs were followed by secondary afterdischarges with durations of 100-500 msec. High-frequency MUA (400 Hz high-pass filter) during IEDs was phase-locked to population-field activity (1-100 Hz bandpass filter) (Fig. 4B). Ictal epileptiform activity consisted of an initial sustained and subsequently intermittent pattern of population discharges (Fig. $4 C$ ). The sustained pattern lasted $4-8 \mathrm{sec}$ and was characterized by rhythmic oscillations of $4-10 \mathrm{~Hz}$ that gradually decreased in frequency and increased in duration and amplitude. This activity was followed by a more intermittent pattern that lasted $21 \pm 4 \mathrm{sec}$ 

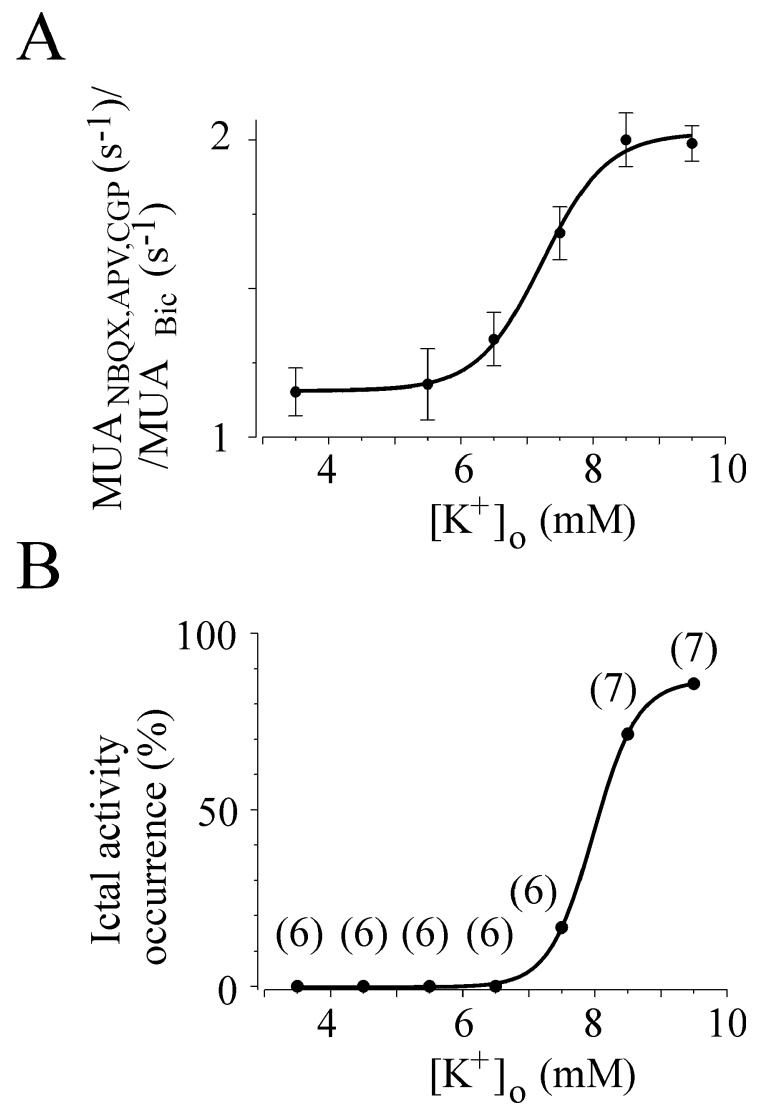

Figure 3. Effects of extracellular potassium and synaptic transmissions on neuronal firing rate and the occurrence of ictal epileptiform patterns in the P10-P11 rat hippocampal slices. $A_{t}$ Extracellular potassium concentration dependence of the effect of bicuculline (10 $\mu \mathrm{m})$ on neuronal firing rate. Ordinates, MUA frequency $\left(\sec ^{-1}\right)$ in NBQX $(10 \mu \mathrm{M})$, D-APV $(50 \mu \mathrm{M})$, and CGP55845 (CGP) (1 $\mu \mathrm{M})$ normalized to MUA frequency $\left(\mathrm{sec}^{-1}\right)$ in bicuculline $(10 \mu \mathrm{M})$ at various concentration of $\left[\mathrm{K}^{+}\right]_{0} . B, 0$ ccurrence of ictal epileptiform activities at different concentrations of extracellular potassium (number of slices).

( $n=4)$ and was characterized by repetitive bursts consisting of initial population spike and secondary afterdischarges. Similar field potentials also have been demonstrated in chronic seizure models in vivo (Bragin et al., 1999b) and in the epileptogenic region of humans with temporal lobe epilepsy (Bragin et al., 1999a). The ictal discharges were followed by a postictal depression with reduced neuronal activity. Continuous application of high $\mathrm{K}^{+}$resulted in recurrent ictal epileptiform activities with a regular interval within a given slice. The interval varied between slices from a minimum of 60 to a maximum of $180 \mathrm{sec}$ (data not shown).

\section{Age-dependent alterations in epileptiform activity}

The expression pattern of high $\left[\mathrm{K}^{+}\right]_{\mathrm{o}}$-induced epileptiform activity was strongly age dependent. Despite increased MUA and synchrony, application of $8.5 \mathrm{~mm}\left[\mathrm{~K}^{+}\right]_{\mathrm{o}}$ failed to induce epileptiform activity in the $\mathrm{P} 0-\mathrm{P} 1$ hippocampal slices, suggesting that the synaptic connectivity of $\mathrm{P} 0-\mathrm{P} 1$ rats is too low to support ictal activities. At P2, $8.5 \mathrm{~mm}\left[\mathrm{~K}^{+}\right]_{\mathrm{o}}$ induced large-amplitude interictal epileptiform discharges $(n=5)$, followed by intermittent ictal discharges and postictal depression $(n=2$ of 5$)$. The intermittent ictal pattern lasted $29.5 \pm 1.2 \mathrm{sec}$ and consisted of epileptiform bursts that decreased in frequency from 3 to $0.5 \mathrm{~Hz}$ and increased in duration and amplitude (Fig. 5A). Starting from P4-P5, ictal activities were characterized by $4-10 \mathrm{~Hz}$ sustained discharges.
A

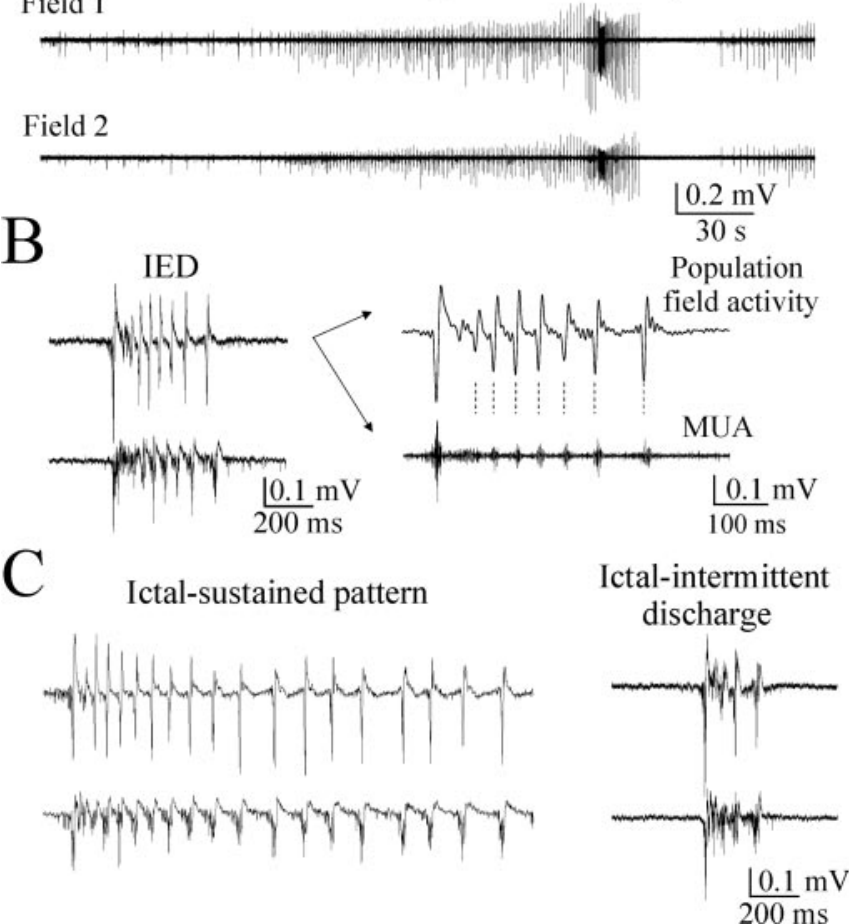

Figure 4. Epileptiform activities induced by $8.5 \mathrm{~mm}$ extracellular potassium in hippocampal slice of a P5 rat. A, Extracellular field potential recordings (wide band, $0.1 \mathrm{~Hz}$ to $10 \mathrm{kHz}$ ) in the pyramidal cell layer of the CA3b (top trace) and CA3a (bottom trace) subregions. Bath application of $8.5 \mathrm{~mm}\left[\mathrm{~K}^{+}\right]_{0}$ induced interictal epileptiform discharges, ictal-sustained and -intermittent discharges, and postictal depression. $B$, Examples of interictal epileptiform discharges on an expanded time scale before filtering (left traces) and after filtering (right traces) for population field activity (1-100 Hz bandpass filter) and MUA ( $400 \mathrm{~Hz}$ high-pass filter). C, Hypersynchronous ictal-sustained and ictal-intermittent epileptiform discharges on an expanded time scale.

Ictal epileptiform activities with this pattern were observed in the hippocampal slices until postnatal day P16. At P15-P16, the sustained phase was characterized by $14-18 \mathrm{~Hz}$ oscillations lasting $8-10 \mathrm{sec}$ (Fig. 5B). Ictus-like activities with the intermittent pattern were observed until P22 (33.3\% of $n=6)$. Only brief epileptiform discharges with an interval of 2-6 sec were observed in hippocampal slices from P23-P30 rats (Fig. 5C), which is similar to what has been found in studies using slices from adult brain (Rutecki et al., 1985; Korn et al., 1987).

Thus, in these in vitro conditions, activation of the neuronal network by elevated extracellular potassium enhanced ictal epileptiform activity propensity in the hippocampal slices from P2P23 rats (Fig. 5D). This developmental window corresponds closely to the window in which GABA has a net excitatory effect, as measured by extracellular multiple-unit activity counting.

\section{Effects of $\mathrm{GABA}_{\mathrm{A}}$ receptor antagonists and agonists on ictal epileptiform activities}

If the net effect of $\mathrm{GABA}_{\mathrm{A}}-\mathrm{R}$ activation in $8.5 \mathrm{mM}\left[\mathrm{K}^{+}\right]_{\mathrm{o}}$ is excitatory in slices from animals younger than P23, then, in contrast to its actions in slices from adult animals (Miles and Wong, 1987), bath application of the $\mathrm{GABA}_{\mathrm{A}}-\mathrm{R}$ antagonists should reduce epileptiform activity. Bicuculline $(10 \mu \mathrm{M})$ reduced the frequency of interictal epileptiform discharges and blocked the ictal sustained epileptiform discharges (100\%) and the ictal intermittent epileptiform discharges $(90 \%)$ evoked by $8.5 \mathrm{~mm}\left[\mathrm{~K}^{+}\right]_{\mathrm{o}}$ in the hippocampal slices from P5-P20 rats $(n=10)$ (Fig. 6A). Low 


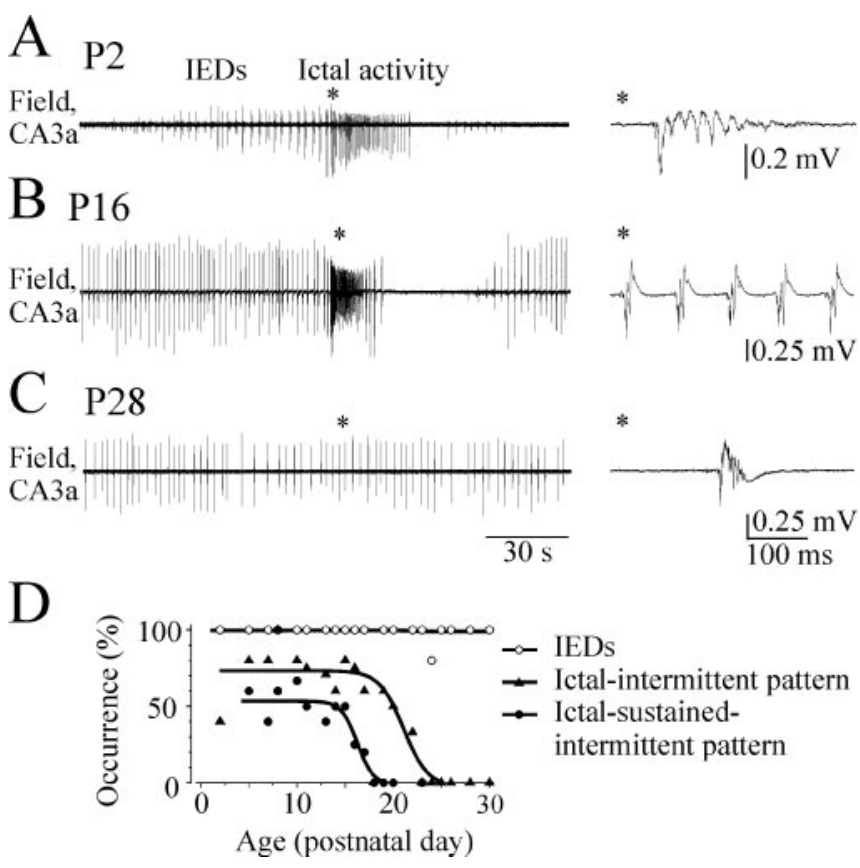

Figure 5. Age-dependent alterations of ictal epileptiform patterns induced in rat hippocampal slices by $8.5 \mathrm{~mm}$ extracellular potassium. A, Example of extracellular field recording from electrode placed in CA3a pyramidal cell layer in P2 hippocampal slice. Bath application of high $\mathrm{K}^{+}(8.5 \mathrm{~mm})$ induced interictal epileptiform discharges, followed by ictal-intermittent discharges and postictal depression. B, At P16, ictus-like activities were characterized by highfrequency ictal-sustained discharges. C, At P28, only brief epileptiform discharges were observed. The events marked by asterisks are shown on extended time scale. D, Developmental profile of $8.5 \mathrm{~mm}\left[\mathrm{~K}^{+}\right]_{0}$ induced epileptiform activities in rat hippocampal slices.

concentrations (200 nM) of the specific competitive $\mathrm{GABA}_{\mathrm{A}}-\mathrm{R}$ antagonist SR95531 (gabazine) reduced the frequency of interictal and ictal epileptiform discharges and decreased duration of ictal epileptiform pattern from $47.6 \pm 3$ to $31 \pm 1.8 \mathrm{sec}(n=9$; $p=0.0002)$ (Fig. $6 B)$. High concentrations $(10 \mu \mathrm{M})$ of SR95531 reduced the frequency of interictal epileptiform discharges further and abolished ictal epileptiform patterns $(n=6)($ Fig. $6 B)$.

In contrast, bath application of the $\mathrm{GABA}_{\mathrm{A}}-\mathrm{R}$ agonist muscimol (200 nM) increased the frequency of ictal epileptiform activities in hippocampal slices from P11-P14 rats $(n=3)$ (Fig. 7A). Low concentrations of the $\mathrm{GABA}_{\mathrm{A}}-\mathrm{R}$ agonist isoguvacine $(2 \mu \mathrm{M})$ decreased ictal epileptiform activity intervals from $155 \pm 7$ to $129 \pm 5 \sec (n=9 ; p=0.006)$ and increased ictal epileptiform activity duration from $35.4 \pm 3$ to $46 \pm 2 \sec (n=9 ; p=0.005)$ (Fig. $7 B)$. Higher concentrations of isoguvacine $(10 \mu \mathrm{M})$ abolished ictal sustained discharges and periodically suppressed the interictal epileptiform discharges. Isoguvacine $(20 \mu \mathrm{M})$ suppressed both ictus-like and interictus-like activities (data not shown). After washing out of isoguvacine, the ictus-like activity recovered rapidly to the control level. These results from young animals are contrary to the anticonvulsant effects of $\mathrm{GABA}_{\mathrm{A}}-\mathrm{R}$ agonists in hippocampal slices from adult rats (Korn et al., 1987).

\section{Discussion}

In this article, we describe developmental changes in the effect of endogenously released GABA, demonstrate that these effects are closely correlated with the propensity of the slice to exhibit ictal epileptiform activity, and demonstrate that GABA antagonists block this ictal epileptiform activity, whereas GABA agonists enhance it. The effects of endogenously released GABA were excitatory up to P12 in control conditions and up to P23 when $\left[\mathrm{K}^{+}\right]_{\mathrm{o}}$

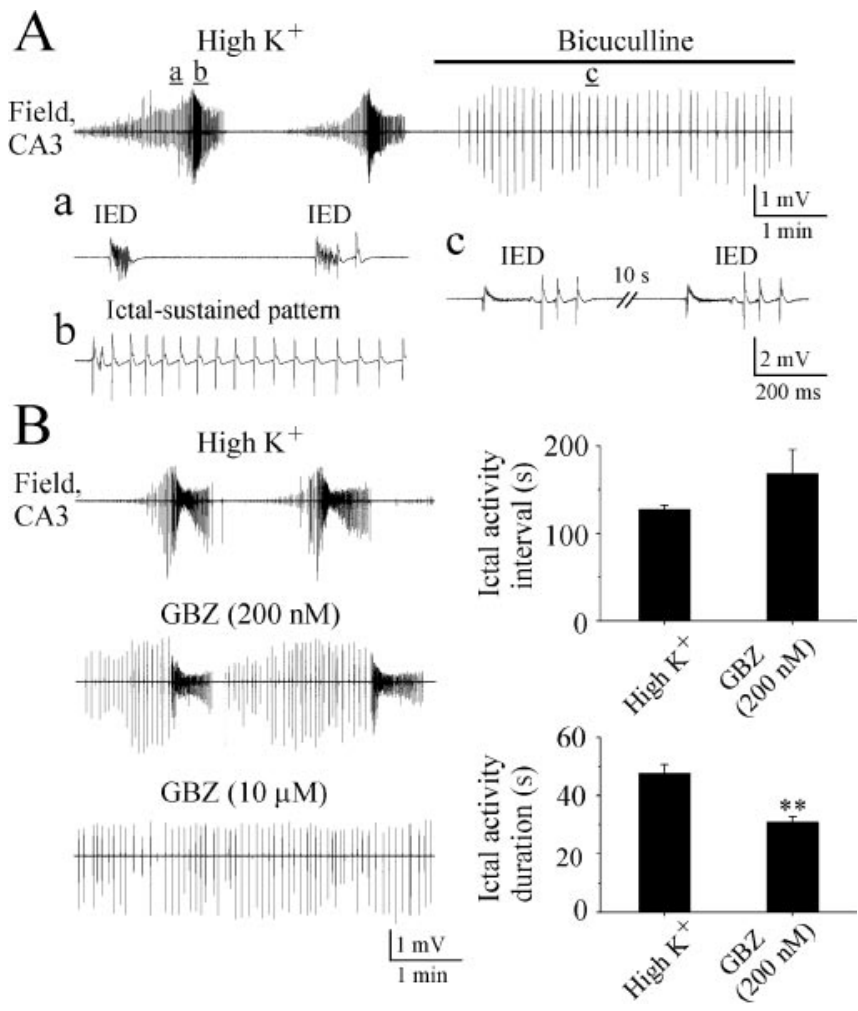

Figure 6. Effects of $G A B A_{A}$ receptor antagonists on high $\mathrm{K}^{+}$-induced epileptiform activities in rat hippocampal slices. $A, \mathrm{GABA}_{\mathrm{A}}$ receptor antagonist bicuculline $(10 \mu \mathrm{m})$ abolished ictal epileptiform discharges and reduced the frequency of interictal epileptiform discharges. The events marked by small letters $(a-c)$ are shown on extended time scale. $B$, Low concentration $(200 \mathrm{nM})$ of the $G A B A_{A}$ receptor antagonist SR95531 [gabazine (GBZ)] increased ictal activity interval and decreased their duration. High concentration (10 $\mu \mathrm{M})$ of SR95531 abolished high $\mathrm{K}^{+}$-induced ictal activity in rat hippocampal slices. $A, B$, Extracellular field potential recordings from the CA3b pyramidal cell layer in P11 and P12 rat hippocampal slices. ${ }^{* *}$ At the $p=0.05$ level, the two means are significantly different.

was increased to $8.5 \mathrm{~mm}$. Ictal epileptiform activity could be elicited by $8.5 \mathrm{~mm}\left[\mathrm{~K}^{+}\right]_{\mathrm{o}}$ up to $\mathrm{P} 23$, i.e., in precisely the same age range in which GABA was excitatory. The concentration-response relationship between $\left[\mathrm{K}^{+}\right]_{\mathrm{o}}$ and the excitatory action of GABA coincided with the concentration-response relationship between $\left[\mathrm{K}^{+}\right]_{\mathrm{o}}$ and in vitro ictal epileptiform activity, providing additional evidence that the excitatory actions of endogenously released GABA are proconvulsant.

The development of hippocampal synapses are driven by early physiological patterns of synchronized neuronal activity (Garaschuk et al., 1998; Leinekugel et al., 2002). GABAergic synapses are established first (Tyzio et al., 1999) and exert an excitatory action as measured by the capacity for $\mathrm{GABA}_{\mathrm{A}}$ receptor activation to trigger action potentials in the postsynaptic cells. $\mathrm{GABA}_{\mathrm{A}}$ receptor-mediated synaptic currents with depolarizing reversal potentials are common in the embryonic and neonatal brain (Serafini et al., 1995; Chen et al., 1996; Warren and Jones, 1997) and are most likely explained by a high intracellular chloride concentration (Owens et al., 1996; Rivera et al., 1999). In addition to triggering action potentials, the depolarizing action of GABA in the neonatal brain may induce $\mathrm{Ca}^{2+}$ entry through voltagedependent $\mathrm{Ca}^{2+}$ channels (Yuste and Katz, 1991; Lin et al., 1994; Leinekugel et al., 1995; Owens et al., 1996), contribute to removal of the $\mathrm{Mg}^{2+}$ block from NMDA channels, and facilitate network activity (Ben Ari et al., 1997) and may thereby trigger and modulate a wide range of developmental processes (LoTurco et al., 1995; Mitchell and Redburn, 1996). 


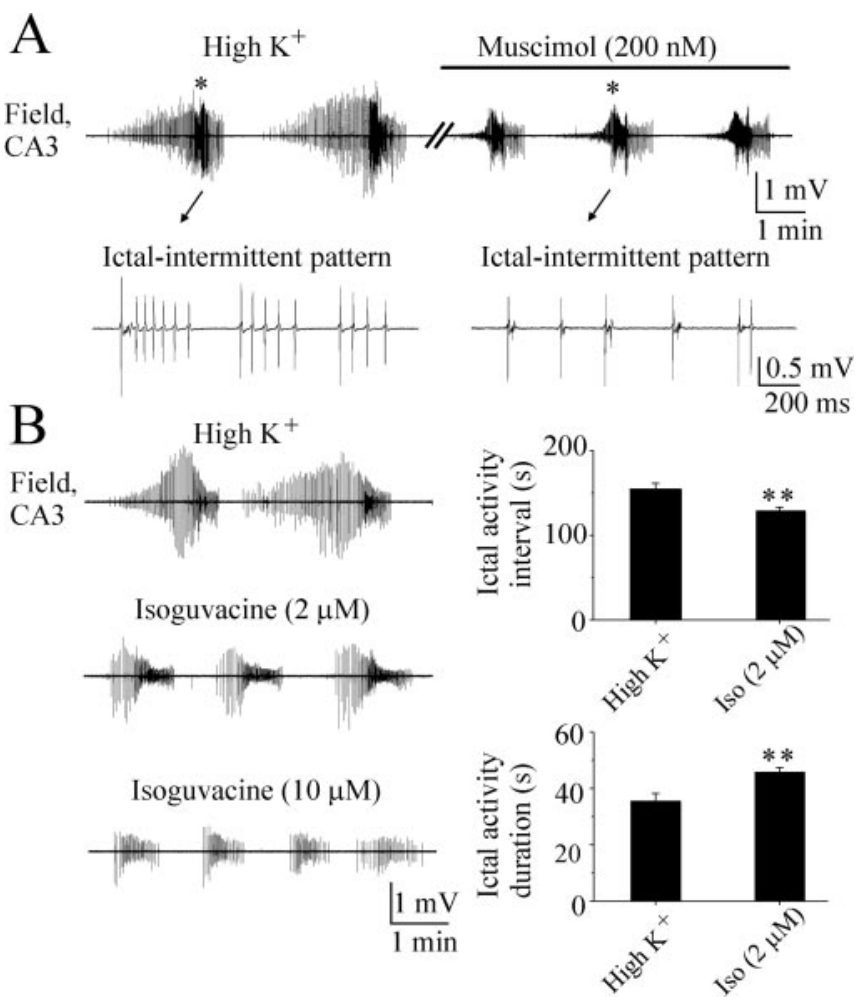

Figure 7. Effects of $G A B A_{A}$ receptor agonists on epileptiform activities in rat hippocampal slices. $A, G A B A_{A}$ receptor agonist muscimol $(200 \mathrm{~nm})$ decreased interval between ictus-like activities in P13 rat hippocampal slice. The events marked by asterisks are shown on extended time scale. $B$, Low concentration of the $G_{A B A_{A}}$ receptor agonist isoguvacine $(2 \mu \mathrm{m})$ decreased ictal activity interval and increased ictal activity duration in P12 rat hippocampal slice. Higher concentration of isoguvacine $(10 \mu \mathrm{m})$ abolished ictal-sustained discharges and periodically suppressed interictal epileptiform discharges. $A, B$, Extracellular field potential recordings from the CA3b pyramidal cell layer in rat hippocampal slices. ${ }^{* *}$ At the $p=0.05$ level, the two means are significantly different.

As development proceeds, GABA gradually becomes less depolarizing and eventually becomes hyperpolarizing. It has been most difficult to determine whether weakly depolarizing GABA responses are excitatory, because depolarizing synaptic responses can still be inhibitory if they shunt more strongly depolarizing excitatory glutamate-mediated currents (Staley and Mody, 1992). Indeed, the large conductance ( $~ 70-90 \mathrm{nS}$ ) of GABAergic synaptic inputs (Connors et al., 1988) and their preferential location between the excitatory inputs and the spike generation zone (Cipolloni et al., 1998) make GABA response an effective shunt for glutamate-induced postsynaptic currents.

In the early postnatal period, when GABA is most strongly excitatory, glutamatergic synaptic connectivity is too low to support ictal epileptiform activity (Traub and Miles, 1991) under normal conditions. As glutamatergic synapses develop over the first 3 postnatal weeks, the GABA response shifts from excitatory to inhibitory, which maintains the stability of the network. The developing neural network can be destabilized by increasing the strength of excitatory glutamatergic synapses, for example, by removing the magnesium block of the NMDA receptor (Wells et al., 2000). The network can also be destabilized by increasing $\left[\mathrm{K}^{+}\right]_{\mathrm{o}}$, as was done in this study. Increasing $\left[\mathrm{K}^{+}\right]_{\mathrm{o}}$ will depolarize the resting membrane potential, so that neurons are closer to action potential threshold. Increasing the extracellular potassium concentration will also decrease the rate at which $\mathrm{Cl}^{-}$can be extruded from the neuron via $\mathrm{K}-\mathrm{Cl}$ cotransport (Thompson and
Gahwiler, 1989b; Staley and Proctor, 1999), which shifts the GABA response toward excitation. The result of these effects is an increase in the age at which endogenously released GABA excites neurons (Figs. $1 C, 2 C$ ). Thus, the important correlation for this study is the age at which ictal epileptiform patterns can be elicited (P23) and the age at which GABA increases action potential firing rate in elevated $\left[\mathrm{K}^{+}\right]_{\mathrm{o}}(\mathrm{P} 23)$.

The finding that ictal epileptiform activities can be generated by high $\left[\mathrm{K}^{+}\right]_{\mathrm{o}}$ in hippocampal slices during the postnatal period from P2 to P23 is earlier than reported previously in in vitro models (Swann and Hablitz, 2000). This may reflect continued improvements in slice preparation techniques and the thicker slices used in this study. We did not find a correlation between spike frequency and electrode depth, indicating that hypoxia in the center of our 700- $\mu \mathrm{m}$-thick slices did not contribute to seizure propensity.

Our data suggest that endogenously released GABA is excitatory and that GABA contributes to ictal activity initiation throughout the developmental window in which $\mathrm{GABA}_{\mathrm{A}}-\mathrm{R}$ activation triggers action potentials. Previous studies have indicated that bath-applied $\mathrm{GABA}_{\mathrm{A}}-\mathrm{R}$ agonists initially increase network activity but then over several minutes inhibit network activity (Khalilov et al., 1999; Lamsa et al., 2000). This is consistent with our findings (Fig. $7 B$ ) and is most easily explained by a rundown in the transmembrane chloride gradient, such that $\mathrm{ECl}^{-}$moves closer to RMP. In the neonatal hippocampus, this move toward RMP is in the negative direction and will decrease $G_{A B A}-R-$ mediated excitation. Endogenously released GABA does not seem to be sufficient to cause this sort of rundown under the conditions studied here. Thus, the net effect of endogenously released GABA is excitatory and contributes to the decreased ictal epileptiform activity threshold in the early postnatal period.

\section{References}

Alger BE, Nicoll RA (1982) Feed-forward dendritic inhibition in rat hippocampal pyramidal cells studied in vitro. J Physiol (Lond) 328:105-123.

Bayer SA (1980) Development of the hippocampal region in the rat. II. Morphogenesis during embryonic and early postnatal life. J Comp Neurol 190:115-134.

Ben Ari Y, Cherubini E, Corradetti R, Gaiarsa JL (1989) Giant synaptic potentials in immature rat CA3 hippocampal neurones. J Physiol (Lond) 416:303-325.

Ben Ari Y, Khazipov R, Leinekugel X, Caillard O, Gaiarsa JL (1997) $\mathrm{GABA}_{\mathrm{A}}$, NMDA and AMPA receptors: a developmentally regulated "menage a trois." Trends Neurosci 20:523-529.

Bragin A, Engel Jr J, Wilson CL, Fried I, Buzsaki G (1999a) High-frequency oscillations in human brain. Hippocampus 9:137-142.

Bragin A, Engel Jr J, Wilson CL, Vizentin E, Mathern GW (1999b) Electrophysiologic analysis of a chronic seizure model after unilateral hippocampal KA injection. Epilepsia 40:1210-1221.

Chen G, Trombley PQ, van den Pol AN (1996) Excitatory actions of GABA in developing rat hypothalamic neurones. J Physiol (Lond) 494:451-464.

Cherubini E, Gaiarsa JL, Ben Ari Y (1991) GABA: an excitatory transmitter in early postnatal life. Trends Neurosci 14:515-519.

Cipolloni PB, Kimerer L, Weintraub ND, Smith DV, Keller A (1998) Distribution of inhibitory synapses on the somata of pyramidal neurons in cat motor cortex. Somatosens Mot Res 15:276-286.

Cohen I, Miles R (2000) Contributions of intrinsic and synaptic activities to the generation of neuronal discharges in in vitro hippocampus. J Physiol (Lond) 524:485-502.

Connors BW, Malenka RC, Silva LR (1988) Two inhibitory postsynaptic potentials, and $\mathrm{GABA}_{\mathrm{A}}$ and $\mathrm{GABA}_{\mathrm{B}}$ receptor-mediated responses in neocortex of rat and cat. J Physiol (Lond) 406:443-468.

DeLorenzo RJ, Towne AR, Pellock JM, Ko D (1992) Status epilepticus in children, adults, and the elderly. Epilepsia 33 [Suppl 4]:S15-S25.

Dzhala V, Khalilov I, Ben Ari Y, Khazipov R (2001) Neuronal mechanisms of the anoxia-induced network oscillations in the rat hippocampus in vitro. J Physiol (Lond) 536:521-531. 
Freund TF, Buzsaki G (1996) Interneurons of the hippocampus. Hippocampus 6:347-470.

Garaschuk O, Hanse E, Konnerth A (1998) Developmental profile and synaptic origin of early network oscillations in the CA1 region of rat neonatal hippocampus. J Physiol (Lond) 507:219-236.

Gomez-Di Cesare CM, Smith KL, Rice FL, Swann JW (1997) Axonal remodeling during postnatal maturation of CA3 hippocampal pyramidal neurons. J Comp Neurol 384:165-180.

Holmes GL (1997) Epilepsy in the developing brain: lessons from the laboratory and clinic. Epilepsia 38:12-30.

Jensen MS, Yaari Y (1988) The relationship between interictal and ictal paroxysms in an in vitro model of focal hippocampal epilepsy. Ann Neurol 24:591-598.

Jensen MS, Yaari Y (1997) Role of intrinsic burst firing, potassium accumulation, and electrical coupling in the elevated potassium model of hippocampal epilepsy. J Neurophysiol 77:1224-1233.

Khalilov I, Esclapez M, Medina I, Aggoun D, Lamsa K, Leinekugel X, Khazipov R, Ben Ari Y (1997) A novel in vitro preparation: the intact hippocampal formation. Neuron 19:743-749.

Khalilov I, Dzhala V, Ben Ari Y, Khazipov R (1999) Dual role of GABA in the neonatal rat hippocampus. Dev Neurosci 21:310-319.

Koch C, Poggio T, Torre V (1983) Nonlinear interactions in a dendritic tree: localization, timing, and role in information processing. Proc Natl Acad Sci USA 80:2799-2802.

Korn SJ, Giacchino JL, Chamberlin NL, Dingledine R (1987) Epileptiform burst activity induced by potassium in the hippocampus and its regulation by GABA-mediated inhibition. J Neurophysiol 57:325-340.

Lamsa K, Palva JM, Ruusuvuori E, Kaila K, Taira T (2000) Synaptic GABA activation inhibits AMPA-kainate receptor-mediated bursting in the newborn (P0-P2) rat hippocampus. J Neurophysiol 83:359-366.

Leinekugel X, Tseeb V, Ben Ari Y, Bregestovski P (1995) Synaptic GABA activation induces $\mathrm{Ca}^{2+}$ rise in pyramidal cells and interneurons from rat neonatal hippocampal slices. J Physiol (Lond) 487:319-329.

Leinekugel X, Khazipov R, Cannon R, Hirase H, Ben Ari Y, Buzsaki G (2002) Correlated bursts of activity in the neonatal hippocampus in vivo. Science 296:2049-2052

Lin MH, Takahashi MP, Takahashi Y, Tsumoto T (1994) Intracellular calcium increase induced by GABA in visual cortex of fetal and neonatal rats and its disappearance with development. Neurosci Res 20:85-94.

LoTurco JJ, Owens DF, Heath MJ, Davis MB, Kriegstein AR (1995) GABA and glutamate depolarize cortical progenitor cells and inhibit DNA synthesis. Neuron 15:1287-1298.

Miles R, Wong RK (1987) Inhibitory control of local excitatory circuits in the guinea-pig hippocampus. J Physiol (Lond) 388:611-629.

Mitchell CK, Redburn DA (1996) GABA and GABA-A receptors are maximally expressed in association with cone synaptogenesis in neonatal rabbit retina. Brain Res Dev Brain Res 95:63-71.

Owens DF, Boyce LH, Davis MB, Kriegstein AR (1996) Excitatory GABA responses in embryonic and neonatal cortical slices demonstrated by gramicidin perforated-patch recordings and calcium imaging. J Neurosci $16: 6414-6423$.
Pedley TA (1980) Interictal epileptiform discharges: discriminating characteristics and clinical correlations. Am J EEG Technol 20:101-119.

Rivera C, Voipio J, Payne JA, Ruusuvuori E, Lahtinen H, Lamsa K, Pirvola U, Saarma M, Kaila K (1999) The $\mathrm{K}^{+} / \mathrm{Cl}^{-}$co-transporter KCC2 renders GABA hyperpolarizing during neuronal maturation. Nature 397:251-255.

Rutecki PA, Lebeda FJ, Johnston D (1985) Epileptiform activity induced by changes in extracellular potassium in hippocampus. J Neurophysiol 54:1363-1374.

Serafini R, Valeyev AY, Barker JL, Poulter MO (1995) Depolarizing GABAactivated $\mathrm{Cl}^{-}$channels in embryonic rat spinal and olfactory bulb cells. J Physiol (Lond) 488:371-386.

Staley K, Smith R (2001) A new form of feedback at the $\mathrm{GABA}_{\mathrm{A}}$ receptor. Nat Neurosci 4:674-676.

Staley KJ, Mody I (1991) Integrity of perforant path fibers and the frequency of action potential independent excitatory and inhibitory synaptic events in dentate gyrus granule cells. Synapse 9:219-224.

Staley KJ, Mody I (1992) Shunting of excitatory input to dentate gyrus granule cells by a depolarizing $\mathrm{GABA}_{\mathrm{A}}$ receptor-mediated postsynaptic conductance. J Neurophysiol 68:197-212.

Staley KJ, Proctor WR (1999) Modulation of mammalian dendritic $\mathrm{GABA}_{\mathrm{A}}$ receptor function by the kinetics of $\mathrm{Cl}^{-}$and $\mathrm{HCO}_{3}{ }^{-}$transport. J Physiol (Lond) 519:693-712.

Swann JW, Hablitz JJ (2000) Cellular abnormalities and synaptic plasticity in seizure disorders of the immature nervous system. Ment Retard Dev Disabil Res Rev 6:258-267.

Thompson SM, Gahwiler BH (1989a) Activity-dependent disinhibition. I. Repetitive stimulation reduces IPSP driving force and conductance in the hippocampus in vitro. J Neurophysiol 61:501-511.

Thompson SM, Gahwiler BH (1989b) Activity-dependent disinhibition. II. Effects of extracellular potassium, furosemide, and membrane potential on $\mathrm{ECl}^{-}$in hippocampal CA3 neurons. J Neurophysiol 61:512-523.

Traub RD, Miles R (1991) Multiple modes of neuronal population activity emerge after modifying specific synapses in a model of the CA3 region of the hippocampus. Ann NY Acad Sci 627:277-290.

Traynelis SF, Dingledine R (1988) Potassium-induced spontaneous electrographic seizures in the rat hippocampal slice. J Neurophysiol 59:259-276.

Tyzio R, Represa A, Jorquera I, Ben Ari Y, Gozlan H, Aniksztejn L (1999) The establishment of GABAergic and glutamatergic synapses on CA1 pyramidal neurons is sequential and correlates with the development of the apical dendrite. J Neurosci 19:10372-10382.

Warren RA, Jones EG (1997) Maturation of neuronal form and function in a mouse thalamo-cortical circuit. J Neurosci 17:277-295.

Wells JE, Porter JT, Agmon A (2000) GABAergic inhibition suppresses paroxysmal network activity in the neonatal rodent hippocampus and neocortex. J Neurosci 20:8822-8830.

Yuste R, Katz LC (1991) Control of postsynaptic $\mathrm{Ca}^{2+}$ influx in developing neocortex by excitatory and inhibitory neurotransmitters. Neuron 6:333344. 